\section{La inflexión inglesa \\ del pensamiento francés}

(1814 - 1848)

Darío Roldán

Darío Roldán es Profesor de la Universidad

Torcuato Di Tella e Investigador del CONICET.

Miñones 2177 (1428) Buenos Aires, Argentina.

E-mail: droldan@utdt.edu

\section{Resumen}

La historia de la inflexión inglesa del pensamiento político francés es la historia del fracaso recurrente de construir una monarquía constitucional y de un legado que asocia la libertad con la limitación del poder, contribuyendo a consolidar la tradición de gobierno parlamentario y facilitando el debate sobre la Constitución europea. El objetivo de este artículo es presentar las tres grandes tradiciones intelectuales que constituyeron esa inflexión, y mostrar que la adecuación entre ella y el principal conflicto planteado por la Restauración fue una de las condiciones de la difusión del modelo inglés a punto tal que, una vez que las condiciones políticas cambiaron, luego de 1848, la referencia inglesa cambia de signo pero, sobre todo, deja de tener significación.
El autor agradece al CONICET, a la Agencia Nacional de Promoción Científica y Tecnológica y a la Fundación Antorchas el apoyo brindado para financiar una parte de la investigación que demandó este trabajo.

\section{Summary}

The history of the English influence on French political thought is the history of a persistent failure in setting up a constitutional monarchy and the history of a legacy that associates liberty with power limits, contributing to consolidate a parliamentary tradition and facilitating the debate concerning the constitution of the European Union. This article presents the three main intellectuals traditions that shaped the English inflection of French political thought. It seeks to analyze the link between these traditions and the major political conflict of the French Restoration (1814-1830) and to explain why after 1848, when the II Republic replaced the Monarchy of July and the nature of political conflict changed, the English reference vanished. 